\title{
Mass Spectral Fragmentation Pattern of trans-1,2-Di-(3-pyridyl)ethylene and trans-1,2-Di(4-pyridyl)ethylene
}

\author{
NeIl G. Keats and Lindsay A. Summers \\ Department of Chemistry, The University of Newcastle, 2308, New South Wales, Australia
}

(Z. Naturforsch. 32 b, 1152-1155 [1977]; received June 13, 1977)

Mass Spectra, trans-1,2-Di(3-pyridyl)ethylene, trans-1,2-Di-(4-pyridyl)ethylene

The mass spectral fragmentation patterns of trans-1,2-di-(3-pyridyl)ethylene and trans1,2-di-(4-pyridyl)ethylene obtained on electron impact have been elucidated. They are more complex than the disintegration pathway observed with trans-1,2-di-(2-pyridyl)ethylene.

The mass spectrum of stilbene (1) has attracted considerable interest ${ }^{1-14}$. It is dominated ${ }^{6}$ by the peaks due to the molecular ion at mass 180 , which is the base peak and the dehydrogenated species M-1 $(85 \%)$ and M-2 $(50 \%)$. The principal initial fragmentation routes involve the unusual loss of $\mathrm{CH}_{3} \cdot$ from the molecular ion to give a peak at mass $165(40 \%)$ and loss of $\mathrm{C}_{2} \mathrm{H}_{2}$ from the M-2 species to give a peak at mass $152(10 \%)$.

We recently reported ${ }^{15}$ the mass spectral fragmentation pattern of trans-1,2-di-(2-pyridyl)ethylene (2). In this case the base peak was due to the $(\mathrm{M}-1)^{\oplus}$ ion, the $\mathrm{M}^{\oplus}$ ion giving rise to a peak of $36 \%$ of the intensity of the base peak. The principal fragmentation routes involved loss of $\mathrm{HCN}$ from the $\mathrm{M}-\mathrm{l}$ ion to afford a $\mathrm{C}_{11} \mathrm{H}_{8} \mathrm{~N}^{\oplus}$ ion at mass $154(9 \%)$ and rupture of one of the pyridyl-CH bonds to afford peaks at mass 104 due to the $\mathrm{C}_{7} \mathrm{H}_{6} \mathrm{~N}^{\oplus}$ ion $(10 \%)$ and at mass 78 due to the $\mathrm{C}_{5} \mathrm{H}_{4} \mathrm{~N}^{\oplus}$ ion $(14 \%)$. The loss of $\mathrm{CH}_{3} \cdot$ was not a significant disintegration pathway. We have now extended this study to an analysis of the fragmentation pathways of trans-

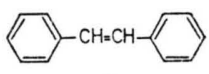

1
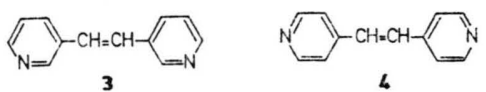

4
Requests for reprints should be sent to Professor L. A. Summers, Department of Chemistry, The University of Newcastle, 2308, New South Wales, Australia. 1,2-di-(3-pyridyl)ethylene (3) and trans-1,2-di-(4pyridyl)ethylene (4). The mass spectrum of 4 has been briefly recorded ${ }^{6}$ but no high resolution mass measurements were reported.

The mass spectrum of trans-1,2-di-(3-pyridyl)ethylene (3) (Fig. 1) is quite different from that

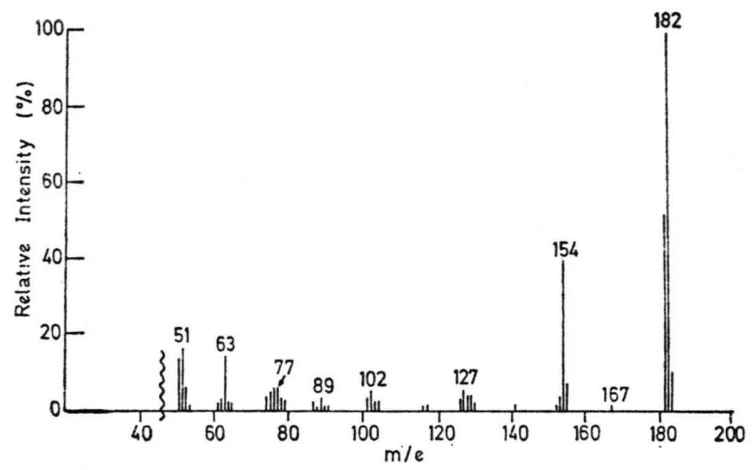

Fig. 1. Mass spectrum of trans-1,2-di-(3-pyridyl)ethylene.

of trans-1,2-di-(2-pyridyl)ethylene (2) ${ }^{15}$ and is more complex. Unlike 2 , the base peak in the spectrum of 3 is due to the molecular ion at mass 182 . The M-1 ion at mass 181 gives rise to a peak of $52 \%$ of the intensity of the base peak. Like 2 , however, and in contrast to the fragmentation of stilbene, the loss of $\mathrm{CH}_{3}$. from the molecular ion of $\mathbf{3}$ is a very minor fragmentation pathway. It produces a small peak $(1 \%)$ at mass 167 due to a $\mathrm{C}_{11} \mathrm{H}_{7} \mathrm{~N}_{2}{ }^{\oplus}$ ion.

Another minor fragmentation route (Scheme 1) from the molecular ion of 3 involves loss of the elements $\mathrm{C}_{2} \mathrm{H}_{3}$ to afford a species of formula 


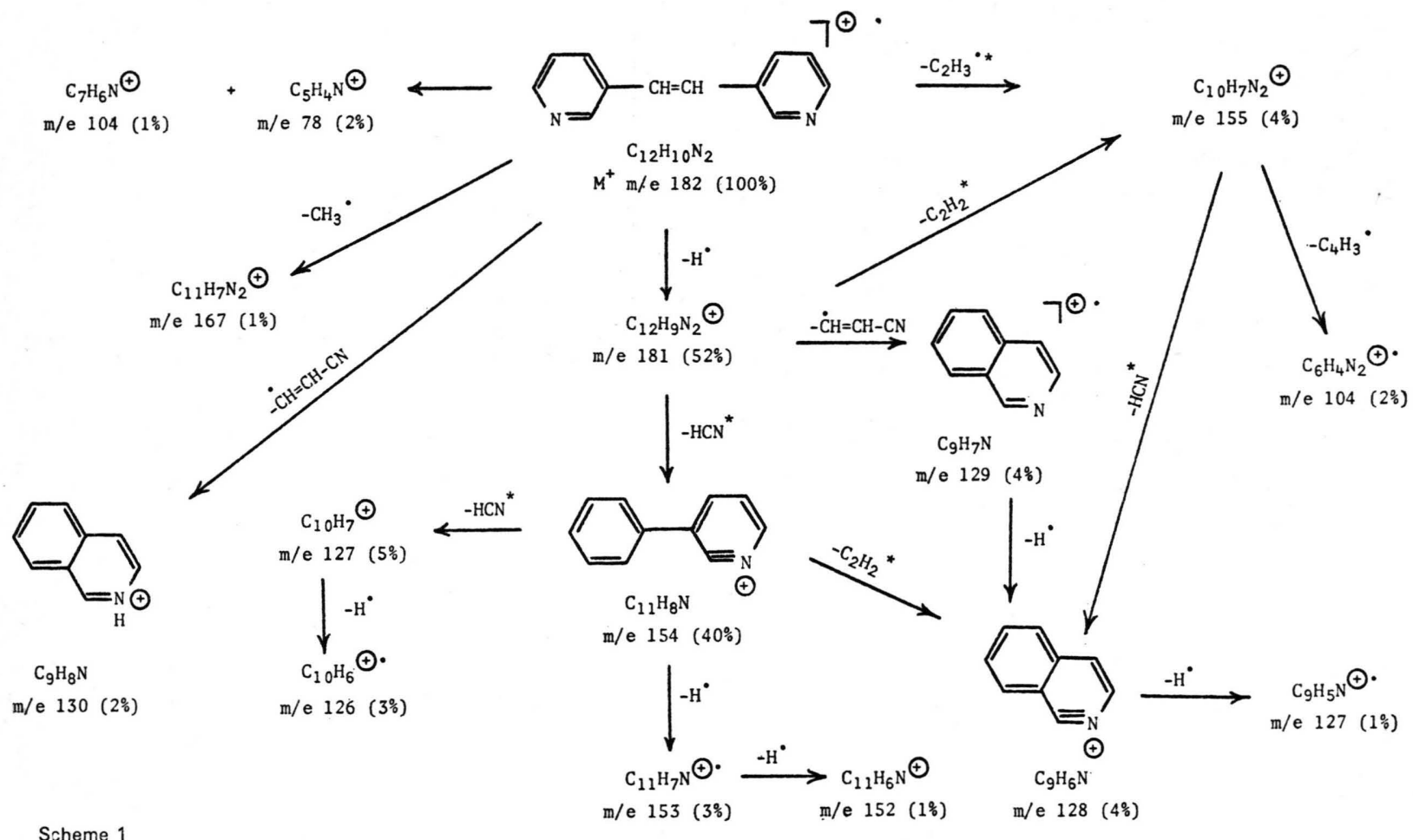

for the small peaks at mass $153\left(3 \% ; \mathrm{C}_{11} \mathrm{H}_{7} \mathrm{~N}^{\oplus \cdot}\right)$.

$\mathrm{C}_{10} \mathrm{H}_{7} \mathrm{~N}_{2} \oplus$ at mass $155(4 \%)$ presumably a bipyridyl molecular ion less one hydrogen. This species is also formed by the loss of $\mathrm{C}_{2} \mathrm{H}_{2}$ from the M-1 ion of 3 at mass 181. Metastable transitions for the fragmentations $182 \rightarrow 155$ and $181 \rightarrow 155$ were present. The analogous losses of $\mathrm{C}_{2} \mathrm{H}_{3}$ and $\mathrm{C}_{2} \mathrm{H}_{2}$ were not observed to any significant extent in the disintegration of 1,2-di-(2-pyridyl)ethylene $(2)^{15}$. The subsequent fragmentation of the $\mathrm{C}_{10} \mathrm{H}_{7} \mathrm{~N}_{2} \oplus$ ion at mass 155 involves loss of $\mathrm{HCN}$. This accounts in part for the peak at mass $128(4 \%)$ due to a $\mathrm{C}_{9} \mathrm{H}_{6} \mathrm{~N}^{\oplus}$ ion considered to be the isoquinoline molecular ion less one hydrogen. A metastable peak for the transition $155 \rightarrow 128$ was observed. The $\mathrm{C}_{10} \mathrm{H}_{7} \mathrm{~N}_{2}{ }^{\oplus}$ ion may also lose $\mathrm{C}_{4} \mathrm{H}_{3}$ and this fragmentation route might account for the major component of the peak at mass $104(2 \%)$ due to a $\mathrm{C}_{6} \mathrm{H}_{4} \mathrm{~N}_{2} \oplus \cdot$ species. No metastable corresponding to the transition $155 \rightarrow 104$ was however observed.

The principal fragmentation route from the molecular ion of 3 involves loss of HCN from the M-1 ion at mass 181. This gives rise to a strong peak $(40 \%)$ at mass 154 due to a $\mathrm{C}_{11} \mathrm{H}_{8} \mathrm{~N}^{\oplus}$ ion probably the 3-phenylpyridine molecular ion less one hydrogen. Loss of hydrogen from the $\mathrm{C}_{11} \mathrm{H}_{8} \mathrm{~N}^{\oplus}$ ion accounts and $152\left(1 \% ; \mathrm{C}_{11} \mathrm{H}_{6} \mathrm{~N}^{\oplus}\right)$. A strong metastable peak is present corresponding to the $181 \rightarrow 154$ transition. The loss of $\mathrm{HCN}$ from the $\mathrm{C}_{11} \mathrm{H}_{8} \mathrm{~N}^{\oplus}$ ion, for which a metastable is observed, accounts for the major component of the peak at mass $127(5 \%$; $\mathrm{C}_{10} \mathrm{H}_{7}{ }^{\oplus}$ ) and further loss of $\mathrm{H} \cdot$ for the peak at mass $126\left(3 \% ; \mathrm{C}_{10} \mathrm{H}_{6} \oplus^{\bullet}\right)$. The $\mathrm{C}_{11} \mathrm{H}_{8} \mathrm{~N}^{\oplus}$ ion also loses $\mathrm{C}_{2} \mathrm{H}_{2}$ and this disintegration provides another source of the $\mathrm{C}_{9} \mathrm{H}_{6} \mathrm{~N}^{\oplus}$ ion at mass 128 .

The small peak at mass $130(2 \%)$ is due to a $\mathrm{C}_{9} \mathrm{H}_{8} \mathrm{~N}^{\oplus}$ ion probably formed from the molecular ion of 3 by loss of $\cdot \mathrm{CH}=\mathrm{CH}-\mathrm{CN}$ although no metastable for the transition $182 \rightarrow 130$ was observed. The $\mathrm{C}_{9} \mathrm{H}_{8} \mathrm{~N}^{\oplus}$ ion is depicted as the isoquinolinium ion. Likewise the $\mathrm{C}_{9} \mathrm{H}_{7} \mathrm{~N}^{\oplus}$. species at mass $129(4 \%)$, considered to be the isoquinoline molecular ion, may be formed by loss of the same elements $\left(\mathrm{C}_{3} \mathrm{H}_{2} \mathrm{~N}\right)$ from the M-1 ion of 3 at mass 181.

The minor component of the peak at mass 104, due to a $\mathrm{C}_{7} \mathrm{H}_{6} \mathrm{~N}^{\oplus}$ ion $(1 \%)$, is presumably formed by rupture of one of the $\mathrm{CH}$-pyridyl bonds of 3 . This fragmentation route from $\mathbf{3}$ is very much less pronounced than the similar bond rupture observed 
with trans-1,2-di-(2-pyridyl)ethylene (2) ${ }^{15}$. The other component of the central bond rupture of 3 , the $\mathrm{C}_{5} \mathrm{H}_{4} \mathrm{~N} \oplus$ ion at mass 78 , is also present only in small amounts $(2 \%)$. In contrast the $\mathrm{C}_{5} \mathrm{H}_{4} \mathrm{~N}^{\oplus}$ ion gave rise to a prominent peak in the spectrum of 215 .

The peaks at mass $103\left(2 \% ; \mathrm{C}_{7} \mathrm{H}_{5} \mathrm{~N}^{\oplus \cdot}\right), 102(5 \%$; $\left.\mathrm{C}_{8} \mathrm{H}_{6} \oplus \cdot\right), 102\left(2 \% ; \mathrm{C}_{7} \mathrm{H}_{4} \mathrm{~N}^{\oplus}\right)$ and $101\left(3 \% ; \mathrm{C}_{8} \mathrm{H}_{5} \oplus\right)$ in the spectrum of $\mathbf{3}$ are typical of those observed from the fragmentation of isoquinoline derivatives ${ }^{16}$. Likewise the peaks below a mass of 100 are largely those to be expected from pyridine and benzene derivatives and require no comment.

The empirical formulae of the ions obtained by high resolution mass measurements are given in Table I. Fragmentation pathways where the ap-

Table I. Empirical formula of fragment ions*.

\begin{tabular}{ll}
\hline Compound & Mass (formula) \\
\hline 3 & $167\left(\mathrm{C}_{11} \mathrm{H}_{7} \mathrm{~N}_{2}\right) ; 155\left(\mathrm{C}_{10} \mathrm{H}_{7} \mathrm{~N}_{2}\right) ;$ \\
& $154\left(\mathrm{C}_{11} \mathrm{H}_{8} \mathrm{~N}\right) ; 153\left(\mathrm{C}_{11} \mathrm{H}_{7} \mathrm{~N}\right) ;$ \\
& $152\left(\mathrm{C}_{11} \mathrm{H}_{6} \mathrm{~N}\right) ; 130\left(\mathrm{C}_{9} \mathrm{H}_{8} \mathrm{~N}\right) ;$ \\
& $129\left(\mathrm{C}_{9} \mathrm{H}_{7} \mathrm{~N}\right) ; 128\left(\mathrm{C}_{9} \mathrm{H}_{6} \mathrm{~N}\right) ;$ \\
& $127\left(5 \% ; \mathrm{C}_{10} \mathrm{H}_{7}\right) ; 127\left(1 \% ; \mathrm{C}_{9} \mathrm{H}_{5} \mathrm{~N}\right) ;$ \\
& $126\left(\mathrm{C}_{10} \mathrm{H}_{6}\right) ; 104\left(1 \% ; \mathrm{C}_{7} \mathrm{H}_{6} \mathrm{~N}\right) ;$ \\
& $104\left(2 \% ; \mathrm{C}_{6} \mathrm{H}_{4} \mathrm{~N}_{2}\right) ; 103\left(\mathrm{C}_{7} \mathrm{H}_{5} \mathrm{~N}\right) ;$ \\
& $102\left(5 \% ; \mathrm{C}_{8} \mathrm{H}_{6}\right) ; 102\left(2 \%_{0} ; \mathrm{C}_{7} \mathrm{H}_{4} \mathrm{~N}\right) ;$ \\
& $101\left(\mathrm{C}_{8} \mathrm{H}_{5}\right) ; 91(\mathrm{M} \oplus \oplus) ; 90\left(\mathrm{C}_{6} \mathrm{H}_{4} \mathrm{~N}\right) ;$ \\
& $89\left(\mathrm{C}_{7} \mathrm{H}_{5}\right) ; 88\left(\mathrm{C}_{7} \mathrm{H}_{4}\right) ; 87\left(\mathrm{C}_{7} \mathrm{H}_{3}\right)$ \\
& $155\left(12 \% ; \mathrm{C}_{11} \mathrm{H}_{9} \mathrm{~N}\right) ; 155\left(3 \% ; \mathrm{C}_{10} \mathrm{H}_{7} \mathrm{~N}_{2}\right) ;$ \\
& $154\left(\mathrm{C}_{11} \mathrm{H}_{8} \mathrm{~N}\right) ; 153\left(\mathrm{C}_{11} \mathrm{H}_{7} \mathrm{~N}\right) ;$ \\
& $152\left(\mathrm{C}_{11} \mathrm{H}_{6} \mathrm{~N}\right) ; 142\left(\mathrm{C}_{10} \mathrm{H}_{8} \mathrm{~N}\right) ;$ \\
& $141\left(\mathrm{C}_{10} \mathrm{H}_{7} \mathrm{~N}\right) ; 140\left(\mathrm{C}_{10} \mathrm{H}_{6} \mathrm{~N}\right) ;$ \\
& $129\left(\mathrm{C}_{9} \mathrm{H}_{7} \mathrm{~N}\right) ; 128\left(7 \% ; \mathrm{C}_{9} \mathrm{H}_{6} \mathrm{~N}\right) ;$ \\
& $128\left(4 \% ; \mathrm{C}_{10} \mathrm{H}_{8}\right) ; 127\left(11 \% ; \mathrm{C}_{10} \mathrm{H}_{7}\right) ;$ \\
& $127\left(1 \% ; \mathrm{C}_{9} \mathrm{H}_{5} \mathrm{~N}\right) ; 126\left(\mathrm{C}_{10} \mathrm{H}_{6}\right) ;$ \\
& $104\left(2 \% ; \mathrm{C}_{7} \mathrm{H}_{6} \mathrm{~N}\right) ; 104\left(2 \% ; \mathrm{C}_{6} \mathrm{H}_{4} \mathrm{~N}_{2}\right) ;$ \\
& $103\left(\mathrm{C}_{7} \mathrm{H}_{5} \mathrm{~N}\right) ; 102\left(4 \% ; \mathrm{C}_{8} \mathrm{H}_{6}\right) ;$ \\
& $102\left(1 \% ; \mathrm{C}_{7} \mathrm{H}_{4} \mathrm{~N}\right) ; 101\left(\mathrm{C}_{8} \mathrm{H}_{5}\right) ;$ \\
& $100\left(1 \% ; \mathrm{C}_{8} \mathrm{H}_{4}\right) ; 100\left(1 \% ; \mathrm{C}_{7} \mathrm{H}_{2} \mathrm{~N}\right) ;$ \\
$99\left(1 \% ; \mathrm{C}_{8} \mathrm{H}_{3}\right) ; 99\left(1 \% ; \mathrm{C}_{7} \mathrm{HN}_{2}\right) ;$ \\
$91\left(\mathrm{M}_{\oplus \oplus} \oplus 90\left(\mathrm{C}_{6} \mathrm{H}_{4} \mathrm{~N}\right) ; 89\left(\mathrm{C}_{7} \mathrm{H}_{5}\right) ;\right.$ \\
$88\left(\mathrm{C}_{7} \mathrm{H}_{4}\right) ; 87\left(\mathrm{C}_{7} \mathrm{H}_{3}\right)$.
\end{tabular}

* Only peaks above mass 80 and $\geqslant 1 \%$ of base peak in intensity are recorded.

propriate metastable transitions were observed are denoted in the Schemes by an asterisk.

The spectrum of trans-1,2-di-(4-pyridyl)ethylene (4) (Fig. 2) is very similar to that of trans-1,2-di(3-pyridyl)ethylene (3) but is quite different from that of trans-1,2-di-(2-pyridyl)ethylene (2). There

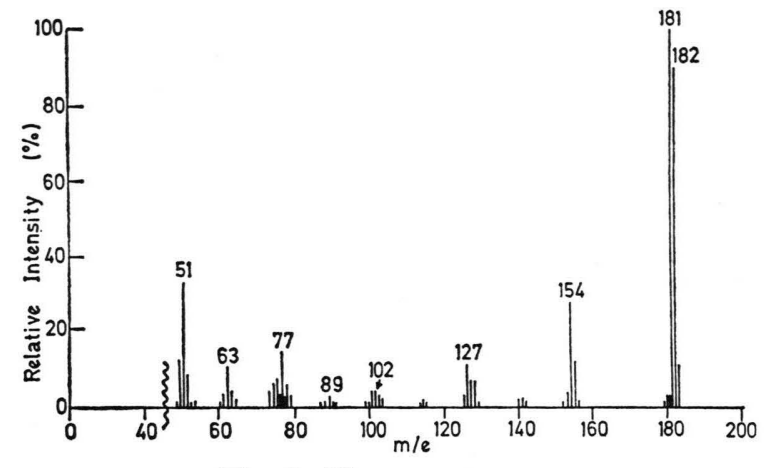

Fig. 2. Mass spectrum of $\operatorname{trans}$-1,2-di-(4-pyridyl)ethylene.

are, however, a few differences between the fragmentation patterns of 3 and 4 (Scheme 2). The most striking difference is that the base peak in the spectrum of 4 is due to the M-1 ion at mass 181 . The $\mathrm{M}^{\oplus}$ ion at mass 182 gives rise to a peak of $90 \%$ of the intensity of the base peak. There is also no significant loss of $\mathrm{CH}_{3}$. from the molecular ion of 4 . The peak at mass 155 is much more pronounced in 4 than in 3. In the spectrum of 4 it is made up of contributions from a $\mathrm{C}_{11} \mathrm{H}_{9} \mathrm{~N}^{\oplus}$. ion $(12 \%)$, presumably the 4-phenylpyridine molecular ion as well as the $\mathrm{C}_{10} \mathrm{H}_{7} \mathrm{~N}_{2}{ }^{\oplus}(3 \%)$ ion observed in the spectrum of 3 . There is a cluster of small peaks $(1-2 \%)$ at mass 142,141 and 140 in the spectrum of 4 . These arise from the loss of $\mathrm{C}_{2} \mathrm{H}_{2} \mathrm{~N}^{\cdot}$ from the molecular ion of 4 giving a $\mathrm{C}_{10} \mathrm{H}_{8} \mathrm{~N}^{\oplus}$ ion at mass 142 followed by loss of hydrogen. This disintegration route is known to occur in both pyridine and $4,4^{\prime}$-bipyridine $^{16}$ but is scarcely present in the case of 3 . Another minor difference between the spectra of 3 and 4 is in the composition of the peak at mass 128. In 4 a substantial contribution to this peak comes from a $\mathrm{C}_{10} \mathrm{H}_{8}{ }^{\oplus}$ species $(4 \%)$, depicted as the naphthalene molecular ion, formed by loss of HCN from the $\mathrm{C}_{11} \mathrm{H}_{9} \mathrm{~N}^{\oplus}$. species at mass 155 . The major component of this peak is, however, due to the $\mathrm{C}_{9} \mathrm{H}_{6} \mathrm{~N}^{\oplus}$ ion $(7 \%)$ as in the spectrum of 3 .

\section{Experimental}

The spectra were determined with an A. E. I. MS-30 mass spectrometer. The samples were analysed by a direct insertion probe at an ionising current of $70 \mathrm{eV}$. The ion source temperature was $100{ }^{\circ} \mathrm{C}$. Elemental compositions were obtained by the peak matching method.

trans-1,2-Di-(3-pyridyl)ethylene ${ }^{17}$ and trans-1,2di-(4-pyridyl)ethylene were analytically pure. 


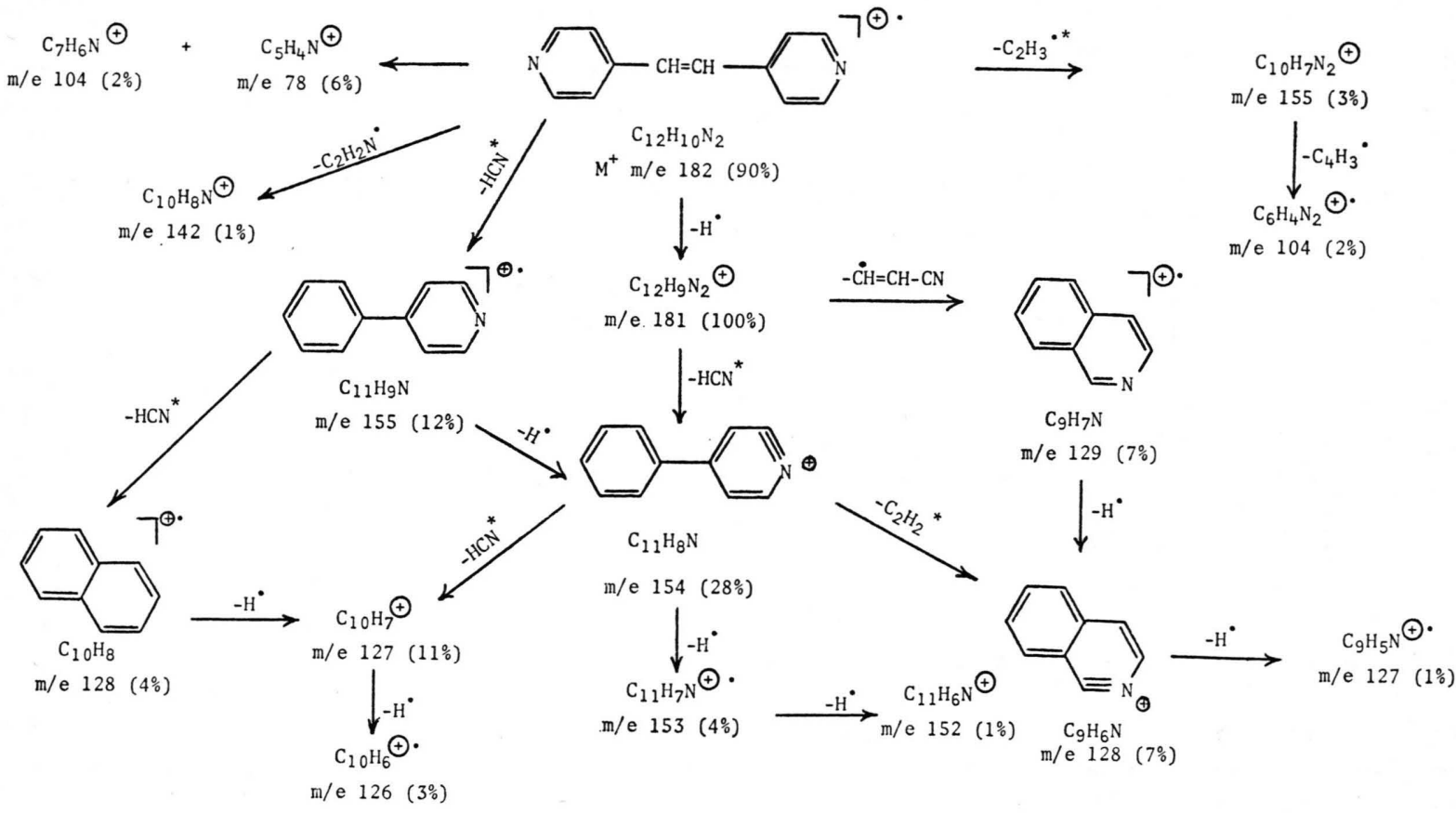

Scheme 2

1 J. H. D. Eland and C. J. Danby, J. Chem. Soc. $1965,5935$.

2 J. G. Pritchard and P. T. Funke, J. Heterocycl. Chem. 3, 209 [1966].

3 R. A. W. Johnstone and B. J. Millard, Z. Naturforsch. 21 a, 604 [1966].

4 A. A. Polyakova, R. A. Khmel'nitskit, I. I. GrandBerg, O. I. Doshlov, and O. R. Khrolova, Zh. Org. Khim. 3, 836 [1967]; C. A. 67, 43240d [1967].

5 R. A. W. Johnstone and S. D. WARd, J. Chem. Soc. (C) 1968, 1805 .

6 R. A. W. Johnstone and S. D. Ward, J. Chem. Soc. (C) 1968, 2540.

7 J. H. Bowie, P. F. Donaghue, H. J. Rodda, and B. K. Simons, Tetrahedron 24, 3965 [1968].

8 P. F. Donaghue, P. Y. White, J. H. Bowie, B. D. Roney, and H. J. Rodda, Org. Mass Spectrom. 2, 1061 [1969].
9 J. H. Bowie and P. Y. White, Aust. J. Chem. 24, 205 [1971].

10 H. Gusten, L. Klasinc, J. Marsel, and D. MilivoJevic, Org. Mass Spectrom. 5, 357 [1971].

11 H. Gusten, L. Klasinc, J. Marsel, and D. MilivoJevic, Org. Mass. Spectrom. 6, 175 [1972].

12 T. Blumenthal and J. H. Bowie, Org. Mass Spectrom. 6, 1083 [1972].

13 R. Engel, D. Halpern, and B. A. Funk, Org. Mass Spectrom. 7, 177 [1973].

14 H. Gusten, L. Klasinc, V. Kramer, and J. MarSEL, Org. Mass Spectrom. 8, 323 [1974].

15 N. G. Keats and L. A. Summers, J. Heterocycl. Chem. 14, 557 [1977].

16 N. G. Keats and L. A. Summers, J. Heterocycl. Chem. 13, 753 [1976].

17 P. Y. White and L. A. Summers, Aust. J. Chem. 30, 1153 [1977] 